

\section{DISCLAIMER}

This report was prepared as an account of work sponsored by an agency of the United States Government. Neither the United States Government nor any agency Thereof, nor any of their employees, makes any warranty, express or implied, or assumes any legal liability or responsibility for the accuracy, completeness, or usefulness of any information, apparatus, product, or process disclosed, or represents that its use would not infringe privately owned rights. Reference herein to any specific commercial product, process, or service by trade name, trademark, manufacturer, or otherwise does not necessarily constitute or imply its endorsement, recommendation, or favoring by the United States Government or any agency thereof. The views and opinions of authors expressed herein do not necessarily state or reflect those of the United States Government or any agency thereof. 


\section{DISCLAIMER}

Portions of this document may be illegible in electronic image products. Images are produced from the best available original document. 


\title{
Techniques Employed for Ultrasonic Thickness Gauging of TRU Plastic Drum Liners
}

\author{
WALTER A. DUDLEY \\ January 9, 1976
}

\section{NOTICE}

This report was prepared as an account of work sponsored by the United States Government. Neither the United States nor the United States Energy Research and Development Administration, nor any of their employees, nor any of their contractors, subcontractors, or their employees, makes any warranty, express or Implied, or assumes any legal liability or responsibility for the accuracy, completeness or usefulness of any information, apperatus, product or process disclosed or represents that its use would not infringe privetelv owned rights.

PRINTED IN THE UNITED STATES OF AMERICA

Avoilable from

National Technical Information Service

U.S. Department of Commerce

5285 Port Royal Road

Springfield, Virginie 22161

Piict: Pinted Copy $\$ 4.00$; Miorofich $\$ 2.25$

\section{MONSANTO RESEARCH CORPORATION}

A Subsidiary of Monsanto Company

\section{MOUND IABORATORY \\ Miamisburg, Ohio \\ 45342 \\ operated for}

\section{UNITED STATES ENERGY RESEARCH AND DEVELOPMENT ADMINISTRATION}

U. S. Government Contract No. E-33-1-GEN-53

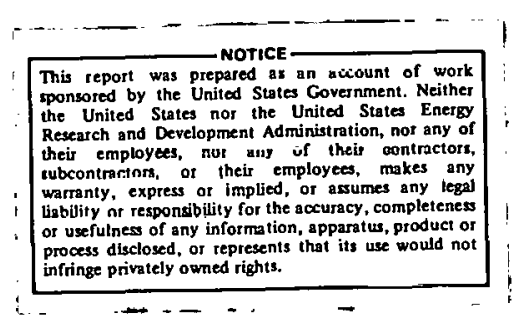




\begin{abstract}
A ratio method and a direct readout method are described for ultrasonic measurement of the wall thickness of plastic drum liners. Although both procedures use the same commercial equipment and give identical results, the direct readout technique is preferred, because it allows an untrained operator to obtain quality results even though a linear change in longitudinal sound velocity as a function of material thickness is occurring.
\end{abstract}

\title{
Introduction
}

Ultrasonic thickness gauging of various materials is becoming a common NDE practice. We had previously used this technique for gauging metals. Presently TRU (Transuranic) packaging material ( a molded plastic drum liner) is being. gauged. The plastic used in the fabrication of the liner is high-density, crosslinked polyethylene, with the cross-linking effected by a resin (Phillips, CLlOOB). The liners are required for long-term and short-term storage of liquid radioactive waste. The plastic must meet rigid compliance specifications to eliminate environmental hazards. One such specification is the minimum acceptable wall thickress of the liner.
To provide quality assurance in this area plus simplification over mechanical gauging, the ultrasonic approach was used. To date two operating techniques have been used: (1) a ratio or comparative method to determine wall thickness, and (2) a direct gauge readout of thickness. Although both procedures give identical results, the latter is preferred since it is simpler for an untrained operator to use; particularly in this case when the longitudinal sound velocity of the material to be measured is not constant with respect to thickness. The general technique for each method along with the results obtained is discussed.

\section{Equipment}

The ultrasonic thickness gauge used for the measurements (see Figure 1) is an Automation Industries unit, model G-2B, and features four-digital readout in mils. The rated accuracy of the gauge for a material thickness range of 20 to $150 \mathrm{mils}$ is $0.1 \mathrm{mil}$. The gauge, as purchased, was designed primarily to function for use with steels, but was provided with internal adjustment to be capable of direct readout on materials with a longitudinal velocity approaching that of copper. Only recently has the gauge been electronically modified to selectively permit a direct readout for plastic materials. Prior to the electronic modification, plastic, as a consequence of its low sound velocity, had to be measured by the ratio method. Specifics of accessory equipment required for gauge operation are listed in Table 1 .

Table 1

ACCESSORY EQUIPMENT REQUIRED FOR GAUGE OPERATION

- AI battery eliminator, Model BE-24.

- Power cord.

- AI transducer, type 57A8910.

- Transducer cable, type RG-174/U, $10 \mathrm{ft}$ long.

- Couplant, Aquasonic 100,

- Calibration standard, plastic and/or steel thickness references as applicablc. 


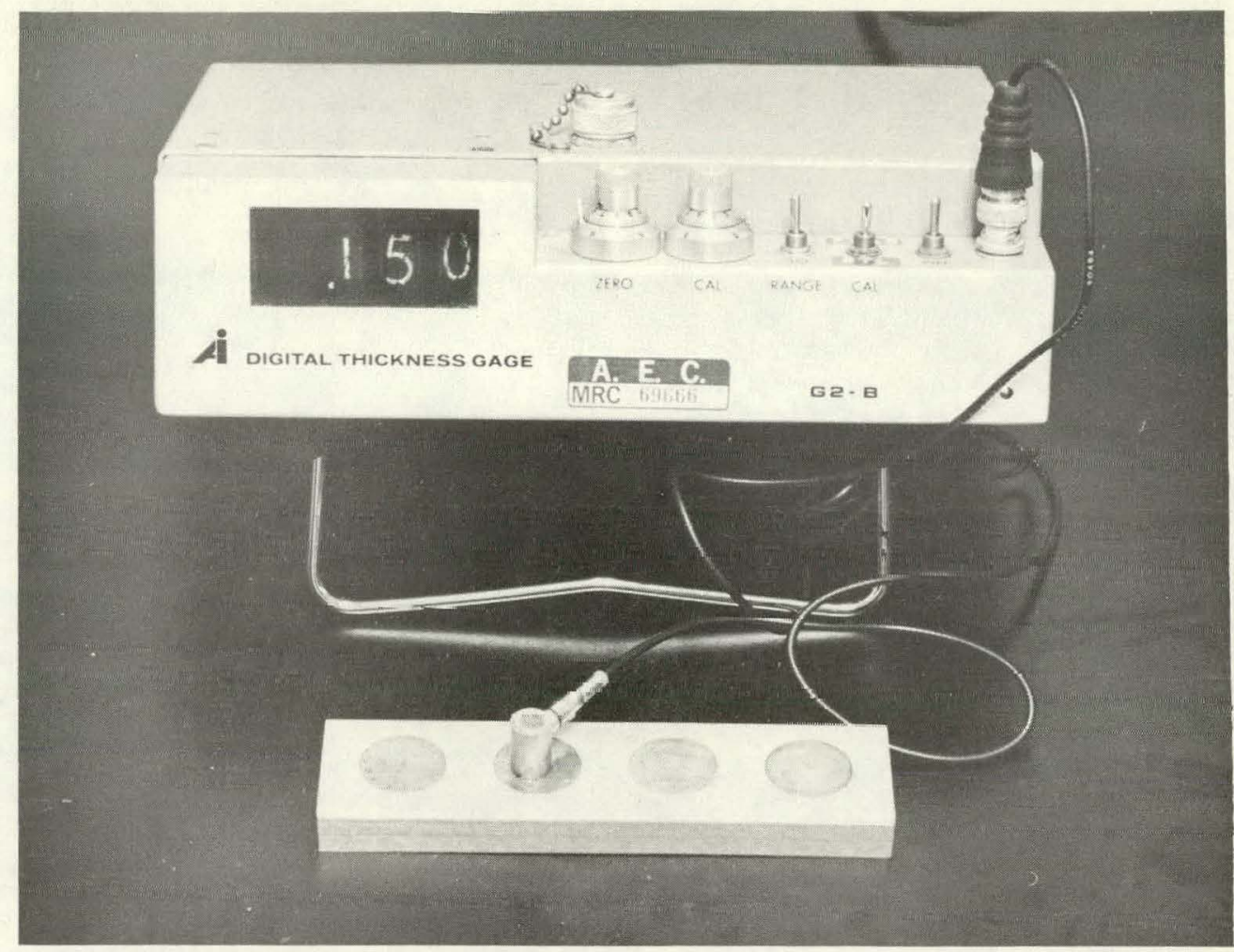

FIGURE 1 - Ultrasonic digital thickness gauges.

\section{Operating Techniques}

\section{RATIO METHOD}

T'o obtain a direct thickness readout with the gauge in its unmodified mode of operation, the material to be measured must have a sound velocity range between steel and copper. Outside this range, as is the case for plastic, the unmodified gauge cannot be directly calibrated for a direct readout in inches. What actually occurs as a result of the calibration limitation imposed on the unmodified gauge is that the travel time (T) of the sound pulse in the material to be measured is always referenced at the readout in mils of an allowed calibration material. Utilization of the "ratio" method of operation relies on the assumption that for two different assymetric materials the ratio of their respective longitudinal sound velocities, $\mathrm{V}_{\mathrm{L}}$, can be considered for all practical purposes to be constant, as expressed in Equation 1 .

$$
\frac{V_{L}(\text { material } \# 1)}{V_{L}(\text { material } \# 2)}=K
$$

However, if this assumption is used with the gauge calibrated against steel reference blocks (type 2340), the obtained plastic thickness readout is erroneous as is quantified by Equation 2

$$
\frac{\text { Incorrect thickness }}{\text { Reading of plastic }}=V_{L} \text { (steel) } \times \mathrm{T}
$$

where $T$ is the sound travel time in plastic.

The incorrect thickness value given by Equation 2 is high in magnitude. To make the gauge read correctly, a multiplicative correction factor equivalent to $\mathrm{V}_{\mathrm{L}}$ (plastic) $/ V_{L}$ (steel) must be applied as shown in Equation 3.

Correct reading

$=$ (incorrect reading) $\frac{V_{L}}{V_{L}} \frac{\text { (plastic) }}{(\text { steel) }}$

$=V_{L} \quad($ stee 1$) \times 1 ' \frac{V_{L}(\text { plastic })}{V_{L}(\text { steel })}$

The ratio factor $V_{L}$ (plastic) $/ V_{L}$ (steel is assumed as previously discussed to be a constant, $\mathrm{K}$, and accordingly Equation 3 can be simply expressed as Equation 4 . 
However, for this particular plastic the obtained $\mathrm{K}$ ratio did not remain constant for increasing thicknesses of plastic. The observed change in the ratio factor as a function of plastic thickness indicated that $\mathrm{V}_{\mathrm{L}}$ (plastic) varied inversely with respect to thickness. This conjecture was verified with conventional pulseecho velocity measurements. The resultant change in the ratio or $\mathrm{V}_{\mathrm{L}}$ (steel)/ $V_{L}$ (plastic) factor as a function of plastic thickness was analytically shown to be linear and expressed by Equation 5 as

$$
C_{R}=2.1887+1.02941 I
$$

where $C_{R}=$ correct ratio and $I=$ incorrect plastic thickness gauge reading in inches.

Thus the true thickness of this particular plastic is given by

Correct Plastic Thickness in Inches $=I / C_{R}$

Table 2 shows the resultant plastic thickness for solution of Equation 6 .

\section{DIRECT READOUT METHOD}

The gauge as recently modified permits the thickness of material with a sound velocity similar to plastic to be measured directly. For this measurement application the modification eliminates the need for using the ratio technique. In addition, the modification alsn eliminatcs any need of operator concern for possible lincar variation in sound velocity as a function of material thickness. The basis for simplication provided by the modification is that the calibration range of the gauge is extended, thus permitting conventional setup using a step block fabricated from the plastic to be measured; that is, the modification permits the calibration coltrols to be adjusted to read the "hi" and "low" steps of the plastic calibration block as absolute. As expected, linear variations in sound velocity as a function of thickness are compensated for electronically for conventional operating procedures.
TO CORRECT PLASTIC THICKINES

\begin{tabular}{|c|c|}
\hline $\begin{array}{c}\text { Plastic } \\
\text { Thickness } \\
\text { (in.) } \\
\end{array}$ & $\begin{array}{l}\text { Gage } \\
\text { Reading } \\
\text { (in.) }\end{array}$ \\
\hline 0.050 & 0.115 \\
\hline 0.055 & 0.128 \\
\hline 0.060 & 0.140 \\
\hline 0.065 & 0.153 \\
\hline 0.070 & 0.165 \\
\hline 0.075 & 0.178 \\
\hline 0.080 & 0.191 \\
\hline 0.085 & 0.204 \\
\hline 0.090 & 0.217 \\
\hline 0.095 & 0.231 \\
\hline 0.100 & 0.244 \\
\hline 0.105 & 0.258 \\
\hline 0.110 & 0.272 \\
\hline 0.115 & 0.286 \\
\hline 0.120 & 0.300 \\
\hline 0.125 & 0.314 \\
\hline 0.130 & 0.329 \\
\hline 0.135 & 0.343 \\
\hline 0.140 & 0.358 \\
\hline 0.145 & 0.373 \\
\hline 0.150 & 0.388 \\
\hline 0.155 & 0.404 \\
\hline 0.160 & 0.419 \\
\hline 0.165 & 0.435 \\
\hline 0.170 & 0.451 \\
\hline 0.175 & 0.467 \\
\hline 0.180 & 0.484 \\
\hline 0.185 & 0.500 \\
\hline 0.190 & 0.517 \\
\hline 0.195 & 0.534 \\
\hline
\end{tabular}




\section{Results}

For the present measurement application, the accuracy of the ratio method of operation has been established as \pm 48 or 5 mils whichever is greater relative to the plastic thickness range given in Table 2 . The large error is attributable to the rough surface condition of the plastic. For the direct readout method, the overall accuracy error will be no worse than that previously established with the ratio technique. However, both methods are inherently capable of an accuracy better than. 1 mil relative to a plastic with flat surfaces.

\section{Conclusion}

As expected, both operating techniques described in this report give identical results. However, the direct readout method with plastic is simpler since conventional procedures can be used as intended in the operational design of the stock gauge. Secondly, the modified gauge permits a nontechnical person to obtain quality measurements regardless of linear velocity effects which might occur. 


\section{Dịstribution}

\section{EXTERNAL}

TID-4500, UC-37 (170)

\section{Consultants}

C. F. Curtiss

University of Wisconsin

C. F. Eck

Miamisburg, Ohio

H. W. Mattson

Monsanto Company

D. F. Griffing

Miami University

R. E. Miers

Ft. Wayne, Indiana

G. W. Poweli

Ohio State University

A. Shapiro

University of Cincinnati

H. F. Swift

University of Dayton Research Institute

D. White

University of Pennsylvania

\section{INTERNAL}

W. G. Brothertion

W. T. Cave

W. A. Dudley (3)

R. K. Flitcraft

J. D. Hastings

F. W. Johncon

L. V. Jones

H. B. Kreider

W. H. Smith

J. M. Tullis

R. E. Vallee

Publications

Library (15)

R. J. Schofield, Bendix Corp.

A. E. Hadden, SRP

R. W. Andrews, GE

K. C. McMillan, LLL

J. P. Cassidy, Pantex

R. Skulski, Rocky Flats

W. D. Stump, Rocky Flats

D. W: Ballard, SLA

A. R. Wilits, SLL

L. E. Burkhart, $Y-12$

D. E. Elliott, LASL

H. K. Nason, MRC 